\title{
Microbiological Characterization and Concerns of the International Space Station Internal Active Thermal Control System
}

\author{
Monsi C. Roman \\ NASA Marshall Space Flight Center, Huntsville, Alabama, USA \\ Paul O. Wieland \\ Wiseland Services, Huntsville, Alabama, USA
}

Copyright $\odot 2005$ SAE International

\begin{abstract}
Since January 1999, the chemical and microbial state of the International Space Station (ISS) Internal Active Thermal Control System (IATCS) fluid has been monitored by analysis of samples returned to Earth. Key chemical parameters have changed over time, including a drop in $\mathrm{pH}$ from the specified $9.5 \pm 0.5$ to $\approx 8.4$, an increase in the level of total inorganic carbon (TIC), total organic carbon (TOC) and dissolved nickel (Ni) in the fluid, and a decrease in the phosphate $\left(\mathrm{PO}_{4}\right)$ level. In addition, silver $(\mathrm{Ag})$ ion levels in the fluid decreased rapidly as $\mathrm{Ag}$ deposited on internal metallic surfaces of the system. The lack of available $\mathrm{Ag}$ ions coupled with changes in the fluid chemistry has resulted in a favorable environment for microbial growth. Counts of heterotrophic bacteria have increased from $<10$ colony-forming units (CFUs) $/ 100 \mathrm{~mL}$ to $10^{6}$ to $10^{7} \mathrm{CFUs} / 100 \mathrm{~mL}$. The increase of the microbial population is of concern because uncontrolled microbiological growth in the IATCS can contribute to deterioration in the performance of critical components within the system and potentially impact human health if opportunistic pathogens become established and escape into the cabin atmosphere. Micro-organisms can potentially degrade the coolant chemistry; attach to surfaces and form biofilms; lead to biofouling of filters, tubing, and pumps; decrease flow rates; reduce heat transfer; initiate and accelerate corrosion; and enhance mineral scale formation. The microbiological data from the ISS IATCS fluid, and approaches to addressing the concerns, are summarized in this paper.
\end{abstract}

\section{INTRODUCTION}

On board, the ISS equipment and crew generate heat. This heat contributes to the overall thermal load on the cabin environment and must be removed. To maintain a comfortable working environment for the crew and to prevent equipment overheating, the thermal control system collects excess heat directly from equipment via conduction to coldplates and internal cooling, and indirectly by removing heat from the atmosphere through forced convection and an air-liquid heat exchanger of the temperature and humidity control subsystem of the Environmental Control and Life Support System. The thermal control system consists of two distinct sections: (1) An internal section that contains heat transport fluid (HTF) to acquire heat, and (2) an external section that uses ammonia $\left(\mathrm{NH}_{3}\right)$ as the working fluid to release heat to space via radiation. These two sections interact through liquid-liquid heat exchangers that transfer heat while maintaining physical separation of the different fluids. The internal section (with the aqueous HTF, called the IATCS) consists of two loops that can be independently operated as a low-temperature ( 3.3 to $5.5^{\circ} \mathrm{C}$ (38 to $\left.42^{\circ} \mathrm{F}\right)$ ) loop (LTL) and a moderate-temperature (16.1 to $18.3^{\circ} \mathrm{C}\left(61\right.$ to $\left.65^{\circ} \mathrm{F}\right)$ ) loop (MTL). In the United States on-orbit segments (USOSs) of the ISS, the MTL has $\approx 200 \mathrm{~L}$ of fluid and the LTL has $63 \mathrm{~L}$ of fluid. These loops can also be operated in single-loop mode, using the loop-crossover assembly, while maintaining their respective temperature ranges.

The HTF formula used in the IATCS is intended to minimize corrosion and microbial growth, as well as to efficiently transport heat. The baseline chemical formula can be found in the Space Station Program (SSP) 30573, revision $\mathrm{B}$ document. [1] Table 1 contains a summary of the HTF baseline chemical requirements as prepared for loading in the ISS USOS: Node 1 (Unity), United States Laboratory (USL) module (Destiny), and Airlock. The program is currently revising the HTF formulation to delete $\mathrm{PO}_{4}$ and $\mathrm{Ag}$. Carbon dioxide $\left(\mathrm{CO}_{2}\right)$ 
Table 1. Chemical Requirements of the HTF

\begin{tabular}{|l|c|}
\hline \multicolumn{1}{|c|}{ Compound } & $\begin{array}{c}\text { Concentration } \\
\text { (mg/L) }\end{array}$ \\
\hline Chlorides & 1 (max) \\
Dissolved oxygen & 6 (max) \\
Total organic carbon & $5(\max )$ \\
Phosphate & $200-250$ \\
Sodium borate & $800-1,200$ \\
Silver sulfate & $0.1-3$ \\
\hline
\end{tabular}

would be used to lower the initial $\mathrm{pH}$ of the fluid from $9.5 \pm 0.5$ to $8.5 \pm 0.5$ while on the ground. An increase in the concentration of borate to possibly minimize the $\mathrm{pH}$ reduction in flight is also being investigated.

The purpose of this paper is to provide a summary of the HTF microbiological analyses and documented results. Pertinent chemical data from the ISS IATCS fluid will also be discussed. In addition, a list of concerns related to microbial growth in the fluid and future work that will address them is provided.

\section{CHEMICAL PARAMETERS}

Changes in the chemistry of the ISS IATCS fluid have been tracked by ground analysis of fluid samples returned from flight. The chemical parameters that could potentially affect the microbial population of the fluid are briefly discussed below.

SILVER - To inhibit microbial growth in the fluid, Ag was included in the HTF formula. The amount of Ag dissolved in the fluid quickly decreases in the IATCS loops due to deposition on metallic surfaces. The "as circulated" concentration is not stated in the SSP specifications; the only requirement that needs to be met is the initial concentration of $\mathrm{Ag}(0.1-3 \mathrm{mg} / \mathrm{L})$ when the fluid is prepared. The concentration of $\mathrm{Ag}$ in the ISS HTF is currently below the detection limit $(<0.002 \mathrm{mg} / \mathrm{L})$, as it has been for most of the operational life of the hardware.

In January 2002, a particulate filter charged with $\mathrm{AgPO}_{4}$ was installed in the ISS IATCS loops. The purpose was to redose the fluid with biocidal $\mathrm{Ag}$ to reduce and control the microbial population. The next sample of fluid returned to the ground, after the installation of the filter, was 4 mo later. No other data are available for the $\mathrm{Ag}$ level in the fluid prior to that sample. From in-flight microbial analysis, it is known that the heterotrophic bacterial population was dramatically reduced-data discussed in this paper-after addition of the $\mathrm{Ag}$. Therefore, it is assumed that the concentration of $\mathrm{Ag}$ was sufficient for temporary microbial control.

Concerns with short-term availability of biocidal $\mathrm{Ag}$ in the fluid, in addition to concerns with material incompatibility, have resulted in an effort to select, test, and implement the use of an alternate antimicrobial additive for the HTF. Current work is being performed to choose an antimicrobial compatible with the IATCS materials that will control the microbial population in the fluid, will not impact the ISS environmental and life support hardware, and in the case of a spill, will be safe for the crew to handle.

$\mathrm{pH}$ - The HTF was formulated to have a pH of $9.5 \pm 0.5$ on orbit; chemical buffers are included to mitigate variations. Due to the higher $\mathrm{CO}_{2}$ levels in the ISS atmosphere than in Earth's atmosphere, and the permeation of $\mathrm{CO}_{2}$ through the Teflon® hoses (and maybe the gas trap), during the first year of operation, the $\mathrm{pH}$ dropped to $\approx 8.4$ as carbonic acid was formed-in excess of what the buffer could accommodate at the specified concentration.

A significant decline of $\mathrm{pH}$ in the ISS HTF was reported from the sample collected in December 2001 (mission UF-1). Before that sample, the concentration was declining slightly but was still close to $\mathrm{pH} 9$. After mission UF-1, the pH stabilized at $\approx 8.5$. It is believed that the decrease of the $\mathrm{pH}$ has stopped and that it in equilibrium with the operating environment.

TOTAL INORGANIC CARBON - TIC concentration-as carbonate-increased in the fluid after exposure to the flight environment. The concentration has stabilized close to $200 \mathrm{mg} / \mathrm{L}$, due to $\mathrm{CO}_{2}$ permeation through the hoses.

TOTAL ORGANIC CARBON - The TOC level is one of the parameters that is closely monitored in the HTF prior to launch. If the TOC level in the fluid exceeds the specified maximum allowable concentration ( $<5 \mathrm{ppm}$ ) after the fluid is circulated in the hardware, the IATCS loop might have to be drained, flushed, and refilled to reduce the concentration. The purpose of controlling the concentration of TOC in the fluid is to minimize the likelihood of microbial growth. A proven way to control microbial growth in water $\left(\mathrm{H}_{2} \mathrm{O}\right)$ systems is to remove essential nutrients that support microbial growth. It has been suggested that one of the main limiting nutrients for microbial growth in $\mathrm{H}_{2} \mathrm{O}$ systems is organic carbon, especially assimilable organic carbon (AOC). $A O C$ is a part of TOC. [2]

Currently, the TOC level in the ISS HTF is well above specifications. The TOC concentration was maintained above specification but was $<25 \mathrm{mg} / \mathrm{L}$ until January 2003 (mission 11A). The next sample, from mission $5 \mathrm{~S}$, had a concentration of $71 \mathrm{mg} / \mathrm{L}$ and has remained at those levels since then. Characterization of the TOC found in the flight samples has found that the increase is due to ethyl alcohol, a chemical that is not traceable to system processing. Contamination is suspected, but the source is unknown at this time. 
PHOSPHATE $-\mathrm{PO}_{4}$ was included in the HTF formula as a corrosion inhibitor, but it also can be a nutrient for microbial growth. The specified level of $\mathrm{PO}_{4}$ is 200 to $250 \mathrm{mg} /$. It stayed within, or very near, this range during most of the first $2 \mathrm{yr}$ of operation. After flight $9 \mathrm{~A}$, however, when the filter in the MTL pump package assembly (PPA) was replaced, the $\mathrm{PO}_{4}$ level declined precipitously, dropping to $\approx 20 \mathrm{mg} / \mathrm{L}$ by flight $7 \mathrm{~S}$. This trend may be related to the increase in TOC, which also occurred after flight 9A. Microbial populations had already been increasing, so any correlation with microbial growth is not so direct. Implementation of a procedure to remove the remaining $\mathrm{PO}_{4}$ to preclude the formation of $\mathrm{NiPO}_{4}$ is currently being considered.

AMMONIA - Low levels of $\mathrm{NH}_{3}$ have been detected in the ISS IATCS fluid since the USL was activated. The $\mathrm{NH}_{3}$ concentration peaked at $0.211 \mathrm{mg} / \mathrm{L}$ in the sample returned on mission 7A, July 2001. Node 1, USL, and Airlock IATCS fluid were not analyzed for $\mathrm{NH}_{3}$ concentration prior to launch. It is possible that the low levels of $\mathrm{NH}_{3}$ detected in the fluid after launch was at least partially due to contamination of the fluid prior to launch. Absorption of atmospheric $\mathrm{NH}_{3}$ through the hoses could also contribute to the $\mathrm{NH}_{3}$ in the fluid. The concentration of $\mathrm{NH}_{3}$ in the ISS cabin is higher $\left(\approx 0.2 \mathrm{mg} / \mathrm{m}^{3}\right)$ than the concentration on the ground.

\section{MICROBIOLOGICAL ANALYSES OF ELEMENTS PRIOR TO LAUNCH}

Documentation of the microbial population in the HTF of Node 1, USL, and Airlock prior to launch is limited because there was no requirement to analyze for microbes at that time. Chemical parameters, as specified in SSP30573, revision B, were used to decide if the fluid was acceptable for charging the elements. The HTF currently in Unity, USL, and Airlock met all the specified chemical parameters prior to launch. In general, the concentration of $\mathrm{Ag}$ in the HTF was low, but there was no requirement for $\mathrm{Ag}$ levels after the fluid was circulated in the elements

NODE 1 - Microbiological analysis (total bacteria count) of the HTF that circulated in Node 1 while on the ground, is summarized in table 2. The fluid samples were collected from the ground support equipment (GSE) coolant servicer (CS) located at the Kennedy Space Center (KSC) Space Station Processing Facility (SSPF). Two samples were sometimes collected from different locations within the GSE, if fluid was available, to analyze duplicate samples. In addition to the analysis summarized in table 2, the microbiology laboratory analyzed for coliforms, anaerobes, and fungi. The results of those analyses were always reported as $<1 \mathrm{CFU} / 100 \mathrm{~mL}$ or no growth (negative).
Node 1 IATCS loops were launched dry. The loops were refilled in flight April 11, 2001, using the fluid system servicer (FSS). The FSS contained $\approx 7 \mathrm{gal}$ of HTF. There is no record of microbiological analysis of the FSS fluid prior to launch.

U.S. LABORATORY - There are records of two USL HTF microbiological analyses performed prior to launch. The first sample was taken during the module functional testing at Marshall Space Flight Center (MSFC) prior to shipping to KSC. The analyses were performed and documented by Boeing's Microbiology Laboratory, Huntsville, AL. Results from the analysis showed that although the $\mathrm{Ag}$ concentration in the solution was low ( 0.035 and $<0.002 \mathrm{mg} / \mathrm{L})$, the bacterial population was maintained relatively low. Counts reported in a March 10, 1999, memorandum were as follow: $2.6 \times 10^{3} \mathrm{CFUs} / 100$ $\mathrm{mL}$ (MTL) and $1 \times 10^{2}$ CFUs/100 $\mathrm{mL}$ (LTL). [3] The organisms identified in those samples were Stenotrophomonas maltophilia, Comamonas acidovorans, and Variovorax paradoxus.

The second record of a microbial analysis performed while the USL was on the ground is in a presentation from Steve Daugherty and John Golden, The Boeing Company. In this presentation, dated November 9, 2000, titled "High TOC Readings in the Lab ITCS Loops and HX's", it is stated that coolant from the USL interface heat exchanger had a microbial count of $<1 \mathrm{CFU} / \mathrm{mL}$. [4] The heat exchanger was not connected to the USL at that time but eventually would be connected. It was also stated in that presentation that the microbial population in the PPA (PN2353170-1-1), which was filled with HTF fluid and stored for $1 \mathrm{yr}$, was $3 \times 10^{6} \mathrm{CFUs} / 100 \mathrm{~mL}$. This part would eventually connect with the USL loops. In the presentation, there is no record of the laboratory that performed the analysis or the methodology used.

AIRLOCK - There is only one documented report of microbial analysis performed on the HTF from Airlock prior to launch. The analysis was performed by KSC's

Table 2. Results of Microbiological Analysis of IATCS Fluid Circulated in Node 1 Prior to Launch

\begin{tabular}{|l|c|l|c|}
\hline \multicolumn{1}{|c|}{ Sample } & $\begin{array}{c}\text { Sample } \\
\text { Date }\end{array}$ & Laboratory & $\begin{array}{c}\text { Results } \\
\text { (CFUs/ } \\
100 \mathrm{~mL} \text { ) }\end{array}$ \\
\hline MTL GSE CS No.1 & $8 / 15 / 97$ & KSC Microbiology & $2.5 \times 10^{1}$ \\
MTL GSE CS No. 2 & $8 / 15 / 97$ & KSC Microbiology & $3.1 \times 10^{1}$ \\
MTL GSE CS No. 1 & $8 / 20 / 97$ & KSC Microbiology & $<1$ \\
MTL GSE CS No. 2 & $8 / 20 / 97$ & KSC Microbiology & $4.24 \times 10^{2}$ \\
MTL GSE & $10 / 6 / 97$ & KSC Microbiology & $1 \times 10^{5}$ \\
LTL GSE & $10 / 6 / 97$ & KSC Microbiology & $1.2 \times 10^{5}$ \\
MTL GSE CS No. 1 & $10 / 17 / 97$ & KSC Microbiology & $7 \times 10^{5}$ \\
MTL GSE CS No. 2 & $10 / 17 / 97$ & KSC Microbiology & $5.7 \times 10^{4}$ \\
\hline
\end{tabular}


Microbiology Laboratory. The sample, collected from the MTL on April 24, 2001, had a microbial count of $3 \times 10^{2}$ CFUs $/ 100 \mathrm{~mL}$.

\section{MICROBIOLOGICAL ANALYSES OF FLIGHT HARDWARE CURRENTLY ON THE GROUND}

NODE 2 - Node 2 is currently on the ground at KSC, being prepared for launch to the ISS. When on orbit, Node 2 HTF fluid will not directly interface with the HTF fluid in the ISS Node 1, USL, and Airlock, which are connected to each other in flight. The chemistry of the HTF in Node 2 is different from the chemistry of the HTF in prior elements and does not contain $\mathrm{PO}_{4}$ or $\mathrm{Ag}$.

Samples identified as "GSE CS" were taken from the ground support equipment coolant servicer at the SSPF. The fluid in this equipment is used to fill the Node loops and to circulate the fluid when needed.

Microbial counts in samples from HTF circulated in the loops of Node 2 are summarized in table 3 . The first two samples-collected on March 2003-were collected while Node 2 was at the Alenia's facility in Turin, Italy. While in Italy, the node was only charged with deionized/ filtered $\mathrm{H}_{2} \mathrm{O}$. The samples were shipped to the Boeing Microbiology Laboratory in ice, but arrived a few weeks later unrefrigerated; therefore, the temperature that the samples were exposed to is unknown.
Results from samples collected on August 5,2004 , were surprising ( $<10 \mathrm{CFUs} / 100 \mathrm{~mL}$ ). The fluid analyzed had been in a mainly stagnant state inside Node 2 loops for almost a year. Chemical analyses of this fluid showed that there was a low level of $\mathrm{Ag}(0.004$ and $0.002 \mathrm{mg} / \mathrm{L})$ and hydrogen peroxide $\left(\mathrm{H}_{2} \mathrm{O}_{2}\right)(0.66$ and $0.78 \mathrm{mg} / \mathrm{L})$ in the solution. $\mathrm{H}_{2} \mathrm{O}_{2}$ is used to disinfect the GSE prior to the preparation and circulation of the HTF. Fluid with Ag was circulated in most of the GSE in the past. Since Ag and $\mathrm{H}_{2} \mathrm{O}_{2}$ were not added to the fluid when it was prepared, the source could be traces of those chemicals in the GSE. It has been documented in literature that low levels of $\mathrm{H}_{2} \mathrm{O}_{2}$ and $\mathrm{Ag}$ can control the microbial population in clean $\mathrm{H}_{2} \mathrm{O}$ systems. [6] It is theorized that the low level of $\mathrm{Ag}$ and $\mathrm{H}_{2} \mathrm{O}_{2}$ controlled the microbial population in the fluid. Low levels of $\mathrm{NH}_{3}$ were also detected in the Node 2 fluid $(0.32$ and $0.24 \mathrm{mg} / \mathrm{L})$. This important finding supports the theory that at least some of the $\mathrm{NH}_{3}$ that was detected in the HTF of the other ISS on-orbit elements was there during ground processing.

Samples collected from the Node 2 GSE on August 24, 2004, were analyzed using two different methodologymembrane filtration and pour plate. [7] Samples were also treated using two different preservatives thiosulfate, used to neutralize halogens and $\mathrm{H}_{2} \mathrm{O}_{2}$, if present, and ethylene diamine tetra acetic acid (EDTA), used to chelate metal ions. Results of the analyses are provided in table 3 . There was a significant (more than

Table 3. Results of Microbiological Analysis of IATCS Fluid Circulated in Node 2

\begin{tabular}{|l|c|l|c|l|}
\hline \multicolumn{1}{|c|}{ Sample } & $\begin{array}{c}\text { Sample } \\
\text { Date }\end{array}$ & Laboratory & $\begin{array}{c}\text { Results } \\
\text { (CFUs/ } \\
100 \mathrm{~mL})\end{array}$ & \multicolumn{1}{|c|}{ Comments } \\
\hline LTL & $3 / 08 / 03$ & Boeing/Huntsville & $3.4 \times 10^{2}$ & H2O sample; Shipping problems \\
MTL & $3 / 08 / 03$ & Boeing/Huntsville & $5.7 \times 10^{4}$ & Same as above \\
LTL & $7 / 29 / 03$ & KSC/Bionetics & $1 \times 10^{3}$ & \\
MTL & $7 / 28 / 03$ & KSC/Bionetics & $6.8 \times 10^{3}$ & \\
LTL & $8 / 28 / 03$ & KSC/Bionetics & $4 \times 10^{2}$ & \\
MTL & $8 / 28 / 03$ & KSC/Bionetics & $1.4 \times 10^{3}$ & \\
LTL & $9 / 10 / 03$ & KSC/Bionetics & $2 \times 10^{2}$ & \\
MTL & $9 / 10 / 03$ & KSC/Bionetics & $4.7 \times 10^{3}$ & \\
LTL GSE CS & $7 / 30 / 04$ & KSC/Bionetics & $2.9 \times 10^{3}$ & \\
MTL GSE CS & $7 / 30 / 04$ & KSC/Bionetics & $1 \times 10^{2}$ & \\
LTL GSE CS & $8 / 02 / 04$ & KSC/Bionetics & $6.5 \times 10^{4}$ & \\
MTL GSE CS & $8 / 02 / 04$ & KSC/Bionetics & $1.04 \times 10^{4}$ & \\
LTL & $8 / 05 / 04$ & Boeing/Huntsville & $<10$ & \\
MTL & $8 / 05 / 04$ & Boeing/Huntsville & $<10$ & \\
MTL GSE CS & $8 / 24 / 04$ & KSC/Bionetics & $9 \times 10^{1}$ & Thiosulfate/Membrane filtration \\
MTL GSE CS & $8 / 24 / 04$ & KSC/Bionetics & $9.4 \times 10^{3}$ & Thiosulfate/Pour plate \\
MTL GSE CS & $8 / 24 / 04$ & KSC/Bionetics & $1 \times 10^{2}$ & EDTA/Membrane filtration \\
MTL GSE CS & $8 / 24 / 04$ & KSC/Bionetics & $2.5 \times 10^{3}$ & EDTA/Pour plate \\
LTL GSE CS & $8 / 24 / 04$ & KSC/Bionetics & $4 \times 10^{2}$ & Thiosulfate/Membrane filtration \\
LTL GSE CS & $8 / 24 / 04$ & KSC/Bionetics & $4.06 \times 10^{4}$ & Thiosulfate/Pour plate \\
LTL GSE CS & $8 / 24 / 04$ & KSC/Bionetics & $1.7 \times 10^{3}$ & EDTA/Membrane filtration \\
LTL GSE CS & $8 / 24 / 04$ & KSC/Bionetics & $8.5 \times 10^{3}$ & EDTA/Pour plate \\
\hline
\end{tabular}


$1 \mathrm{log}$ ) difference in the heterotrophic bacterial population isolated from the samples using the different methodology. Further work is needed to establish if the difference was due to the preservative, the methodology, or both.

PAYLOAD RACKS - There is a good record of microbial analysis from ISS experimental rack fluid while on the ground. These data can be used to understand the microbial load that the ISS IATCS loops (Node 1, USL, and Airlock) were exposed to in the past.

The HTF (SSP30573, rev. B) in the racks is idle most of the time while stored at KSC. It is circulated periodically and duplicate samples are collected for microbial/ chemical analysis. At that time, the fluid that was stored in the rack mixes with the fluid in the GSE during circulation. Analysis of the data can be further complicated because the racks are sometimes flushed or disinfected if the microbial load is considered high. Data from four racks is discussed in this paper. The racks selected were the Human Research Facility flight rack 2 (HRF-2), minus eighty-degree laboratory freezer for ISS flight unit 1 (MELF/-1), and expedite the processing of experiments to Space Station (EXPRESS) racks 6 (ER-6) and ER-7. Data from those racks are presented in figures $1-4$. Microbial levels $<1 \times 10^{4}$ should be considered good. Microbial levels $>1 \times 10^{4}$ but $<1 \times 10^{5}$ should be flagged, and levels $>1 \times 10^{5}$ should be considered high.

\section{MICROBIOLOGICAL ANALYSES OF FLEET LEADER GROUND TEST}

Intended to provide advance indication of changes in conditions of the flight IATCS, a subscale test bed was constructed at MSFC and activated on September 5, 2000 , prior to launch of the USL module. This test bed is referred to as the Fleet Leader and was designed to be materially similar to the flight IATCS and to allow for monitoring of HTF chemistry; microbial growth, including biofilm development; and other system characteristics. A major purpose of the Fleet Leader was to evaluate the growth and effects of micro-organisms in the HTF and on internal surfaces of the IATCS components. Microbial analyses included monthly monitoring of free-floating (planktonic) micro-organisms in the HTF and periodic analyses of surfaces for attached micro-organisms and biofilm development. Analytical techniques include heterotrophic plate counts on R2A media to determine the viable bacterial population, scanning electron microscopy to determine the presence of biofilm on surfaces, and energy-dispersive $x$-ray spectroscopy to determine the presence of inorganic contamination.

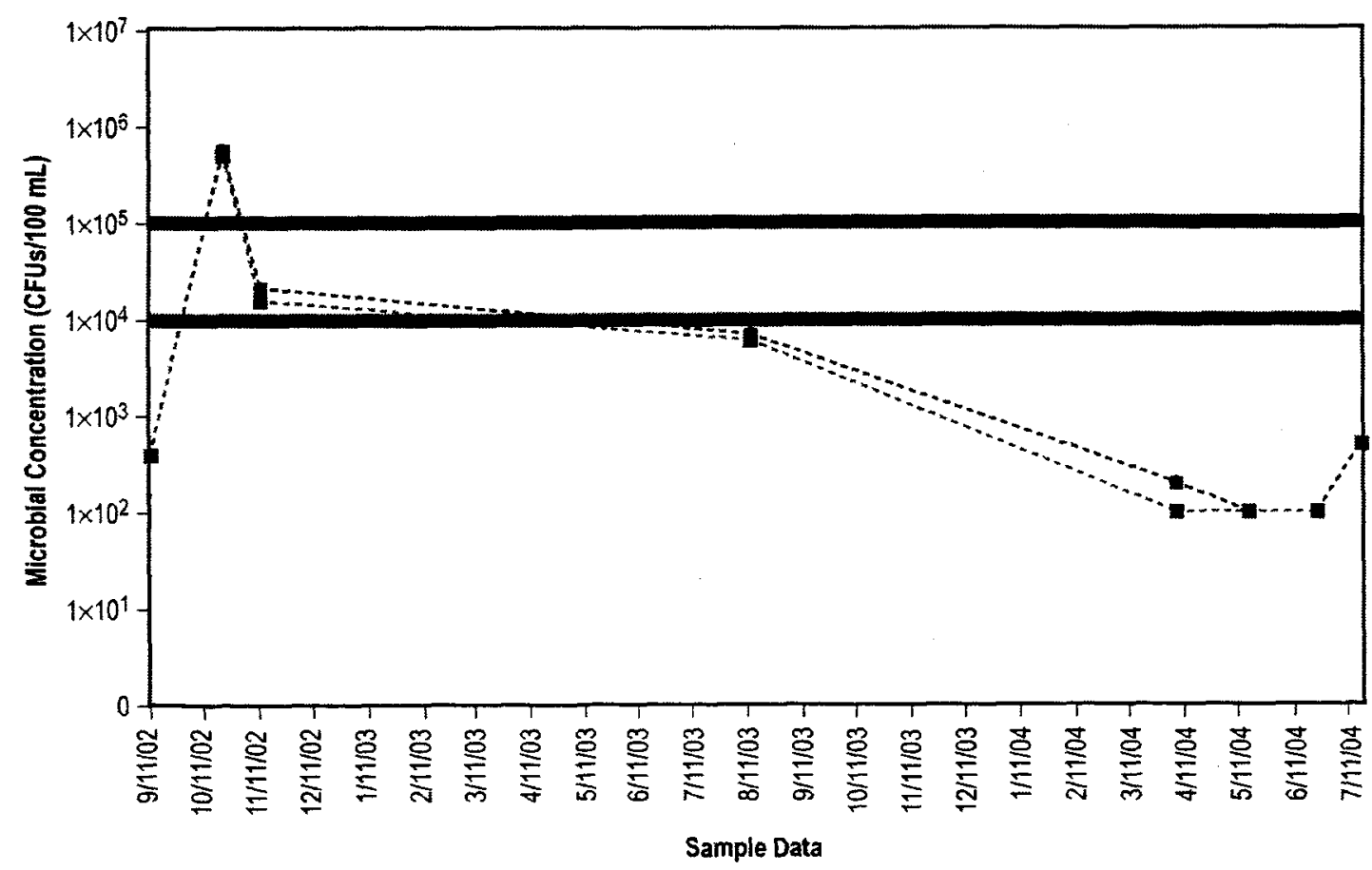

Figure 1. Microbial Concentrations in Duplicate Samples of HTF in ER-6 Payload Rack 


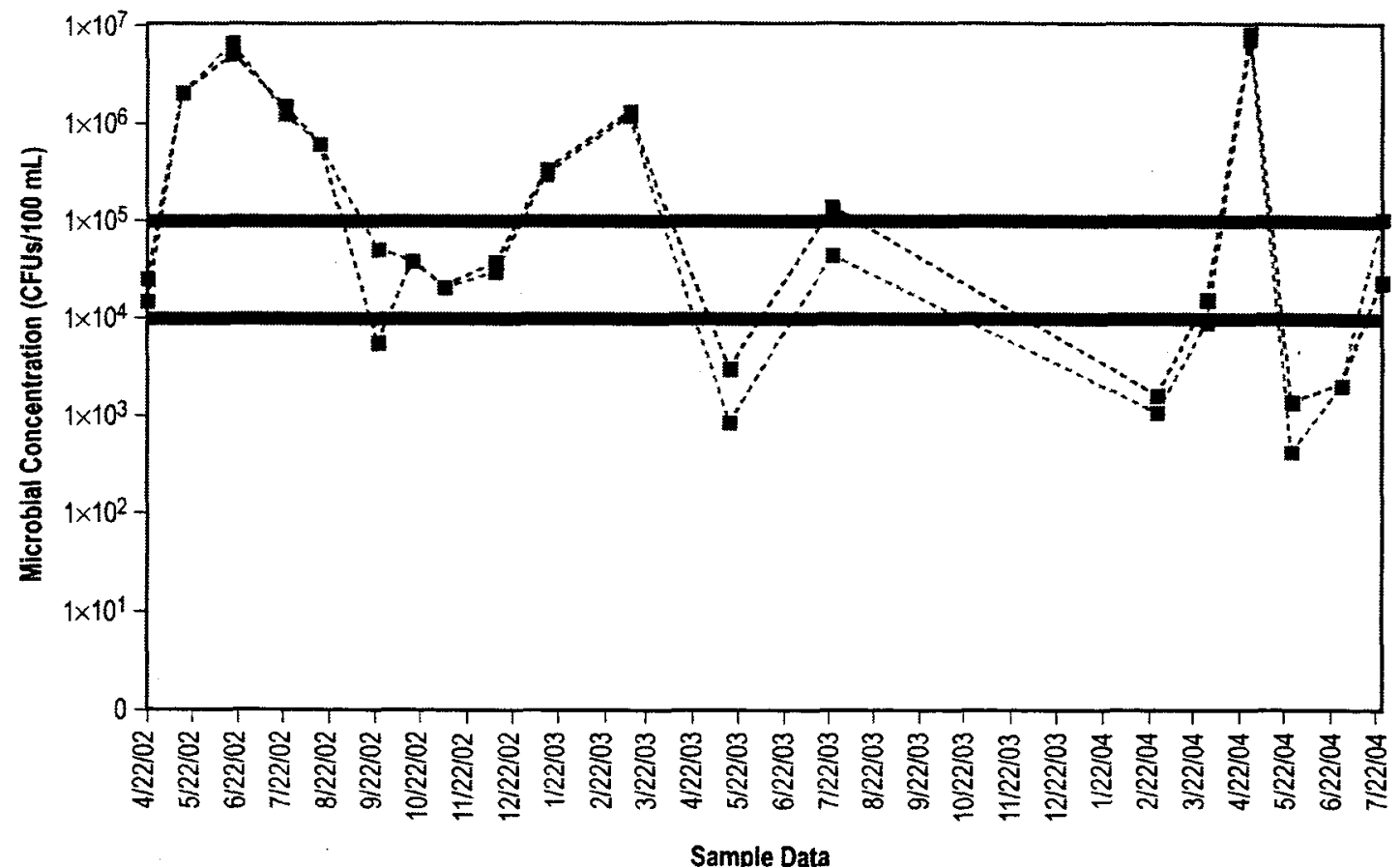

Figure 2. Microbial Concentrations in Duplicate Samples of HTF in ER-6 Payload Rack

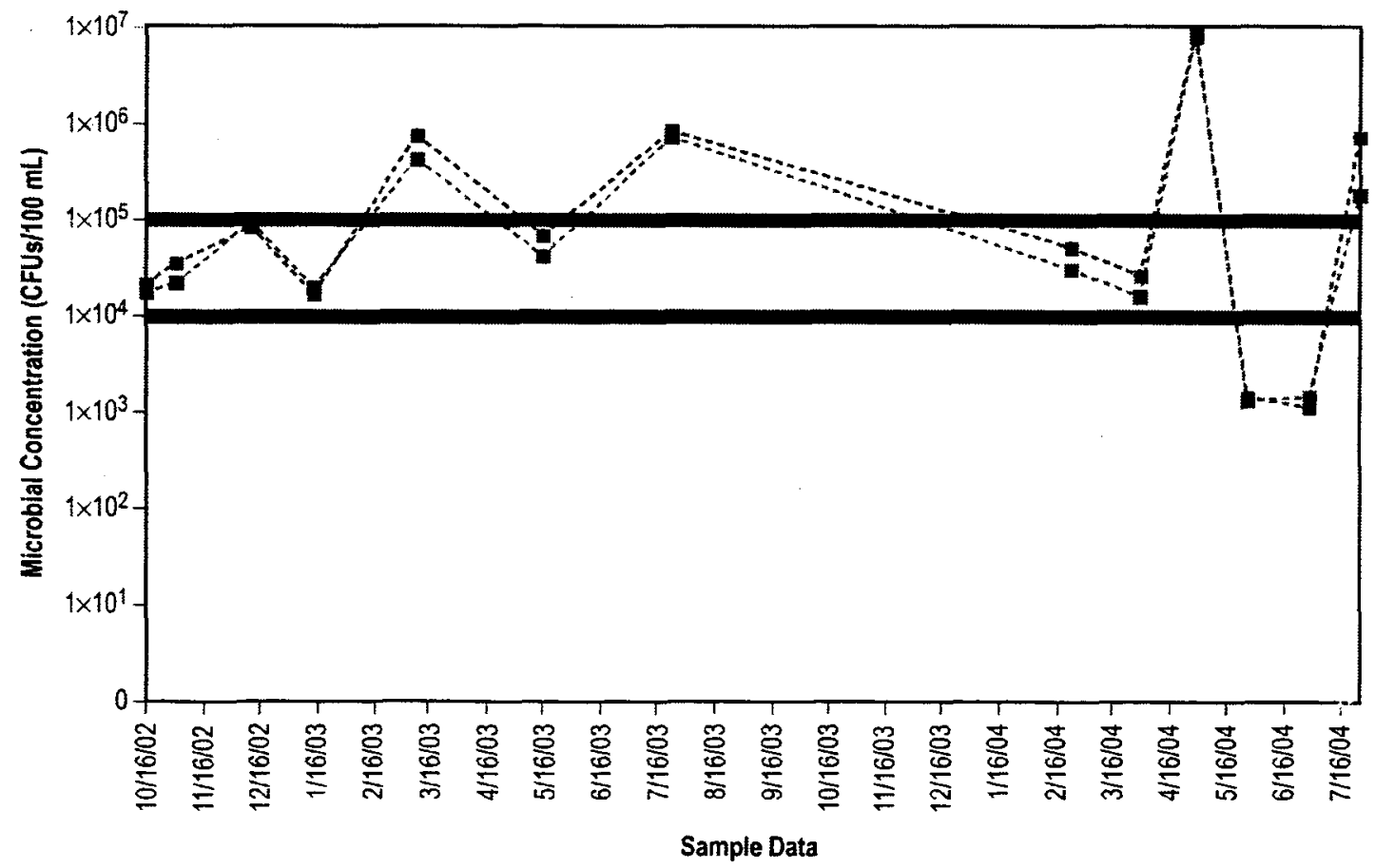

Figure 3. Microbial Concentrations in Duplicate Samples of HTF in ER-7 Payload Rack 


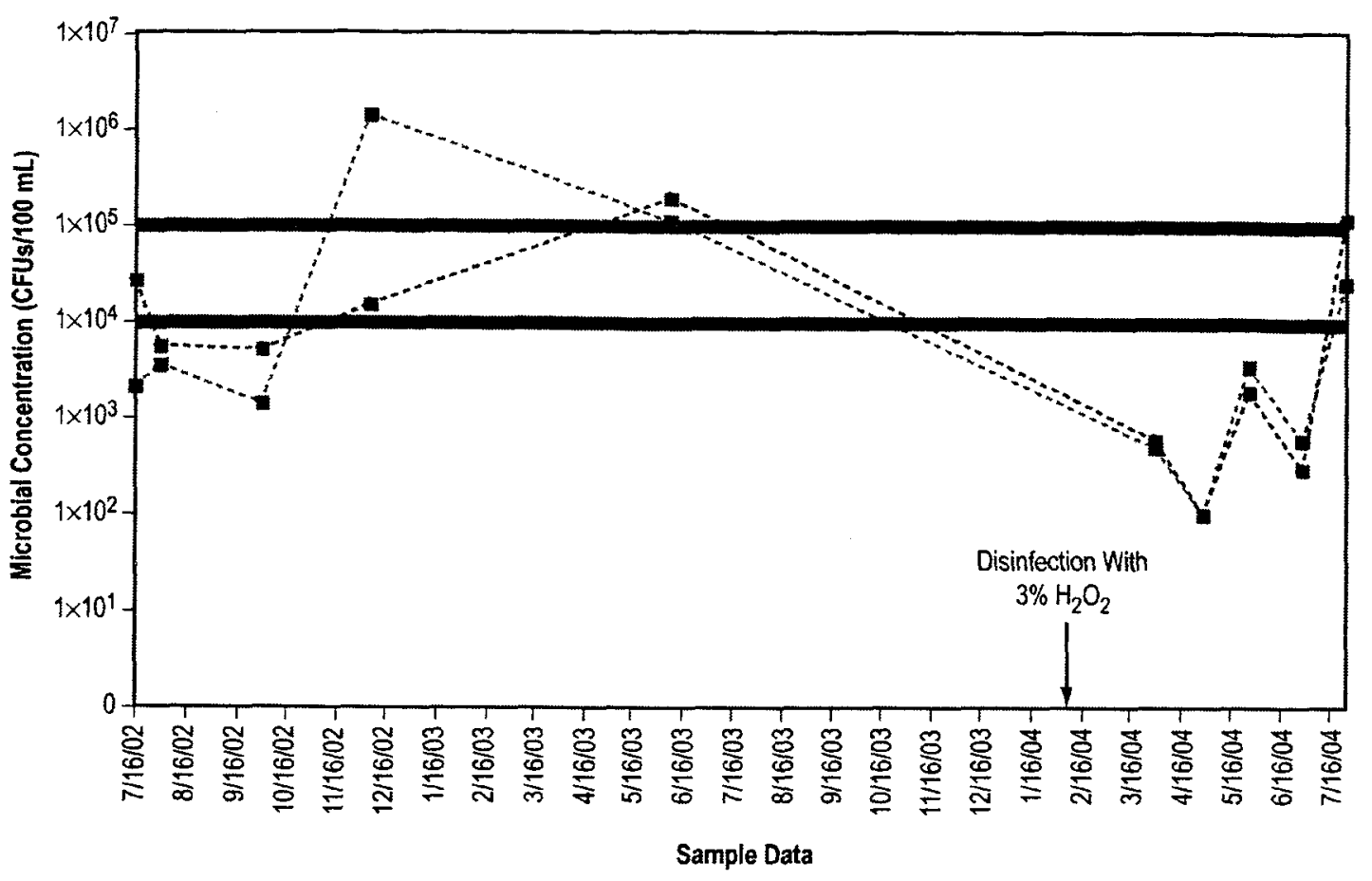

Figure 4. Microbial Concentrations in Duplicate Samples of HTF in MELFl-1 Payload Rack

Results for the first $2 \mathrm{yr}$ of the test indicated that the planktonic microbial population in the HTF was stable (within $1 \mathrm{log}$ ), as shown in figures 5 and 6 . During this period, the TOC and $\mathrm{pH}$ were stable-within the specified ranges, also shown in figures 5 and 6 , respectively. Monitoring of TIC was initiated near the end of the first $2 \mathrm{yr}$ and the level was less than $\approx 10 \mathrm{mg} / \mathrm{L}$.

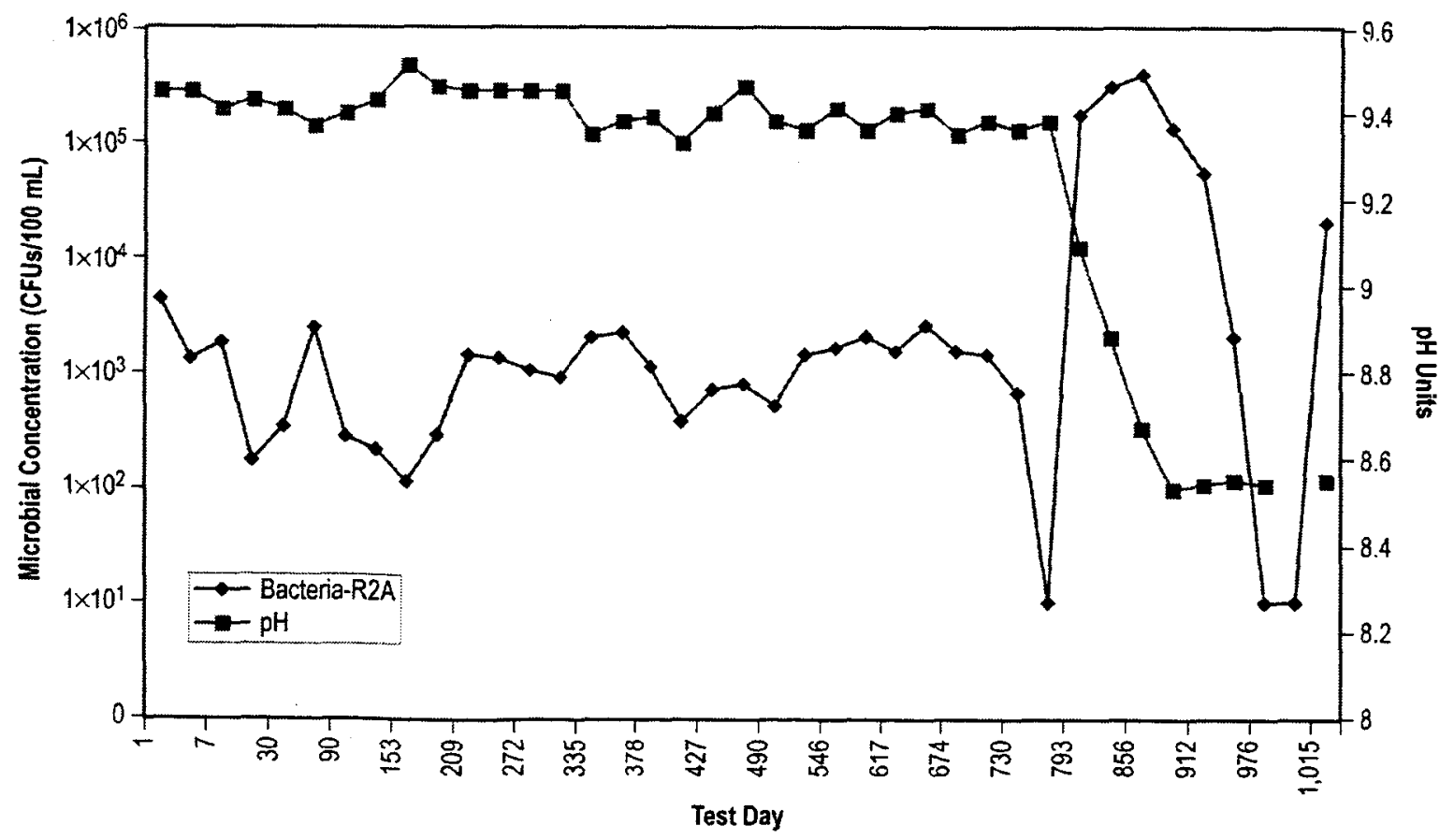

Figure 5. Microbial Concentration Versus pH of the Fleet Leader Ground Test 


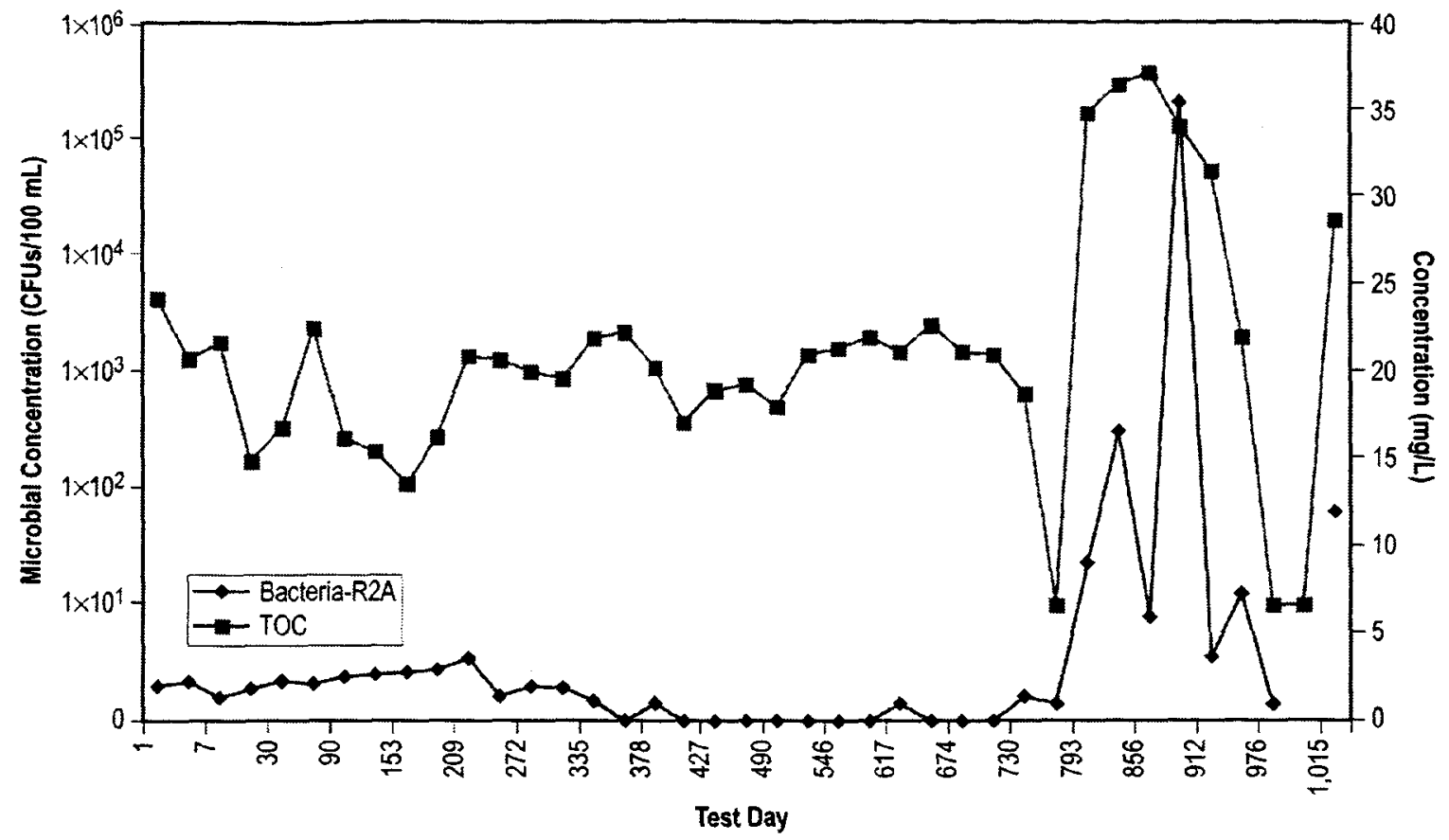

Figure 6. Microbial Concentration Versus TOC in HTF of the Fleet Leader Ground Test

Because the Fleet Leader did not exhibit changes in the flight HTF, after the second year of operation, a slight modification was made to more closely match the flight condition and to evaluate a hypothesis for a contributing cause of the changes in flight. The large Teflon $®$ hose of the test bed was wrapped in a plastic bag and pure $\mathrm{CO}_{2}$ was injected into the bag at ambient pressure and temperature. Within $3 \mathrm{mo}$, the $\mathrm{pH}$ of the HTF had dropped to $\approx 8.4$, matching the flight condition, and verifying that $\mathrm{CO}_{2}$ does significantly permeate the Teflon® hoses. The $\mathrm{CO}_{2}$ injection was then replaced with mixed gas representative of the oxygen, nitrogen, $\mathrm{CO}_{2}$, and $\mathrm{NH}_{3}$ concentrations in the ISS atmosphere. As the $\mathrm{pH}$ decreased, the level of dissolved $\mathrm{Ni}$ in the HTF increased, and the microbial population fluctuated with a dramatic increase from $10^{3}$ to $10^{5}$ CFUs $/ 100 \mathrm{~mL}$ before declining to $10^{4}$. The drops to $10^{1}$ CFUs $/ 100 \mathrm{~mL}$ are due to a bad data point-near day 790 -and inadvertent overheating of the test bed to over $135^{\circ} \mathrm{F}$ for $42 \mathrm{hr}$ (near day 990, in April 2003). This indicates a possible disinfection method for use during ground processing or in flight.

The micro-organisms identified before and after the initiation of $\mathrm{CO}_{2}$ injection are shown in figures 7 and 8 , respectively. The changes are noticeable, including the isolation of previously undetected species and an increase in Variovorax paradoxus. It appears that the $\mathrm{pH}$ change had an effect in the bacterial concentration and the types of micro-organisms identified.

\section{MICROBIOLOGICAL ANALYSES OF ISS IATCS FLUID SAMPLES}

Characterization of the ISS IATCS fluid microbial load has been limited by the amount of fluid that can be returned from flight and by the fact that the samples cannot be refrigerated while in transit from the ISS to KSC. Holding times between the time the sample is collected and the time the sample is analyzed have fluctuated from 4 to $87 \mathrm{~d}$. The microbial parameter that has been consistently performed is culturing of heterotrophic bacteria on R2A medium. Other microbial analyses that have been performed, if fluid was available, include the biological activity reaction test for sulfate-reducing bacteria, iron-related bacteria, acid-producing bacteria, slimeproducing bacteria, nitrifying bacteria, and denitrifying bacteria.

Concentration of heterotrophic bacteria in the fluid has increased from $<10$ to $1 \times 10^{7}$ CFUs $/ 100 \mathrm{~mL}$ since the first samples were returned to the ground for analysis in October 2000. Figure 9 contains the results of the ISS IATCS fluid microbial analysis, indicating that since late 2002, the microbial population in the fluid has not significantly varied. The microbial population is stable in a stationary phase. The decrease in the microbial population in April 2002 is due to the $\mathrm{Ag}$ that was added to the fluid in January 2002. As the available Ag concentration decreased, the microbial population started to increase. It is possible that if Ag was not added to the fluid in January 2002, the fluid would have reached the stationary phase earlier. 


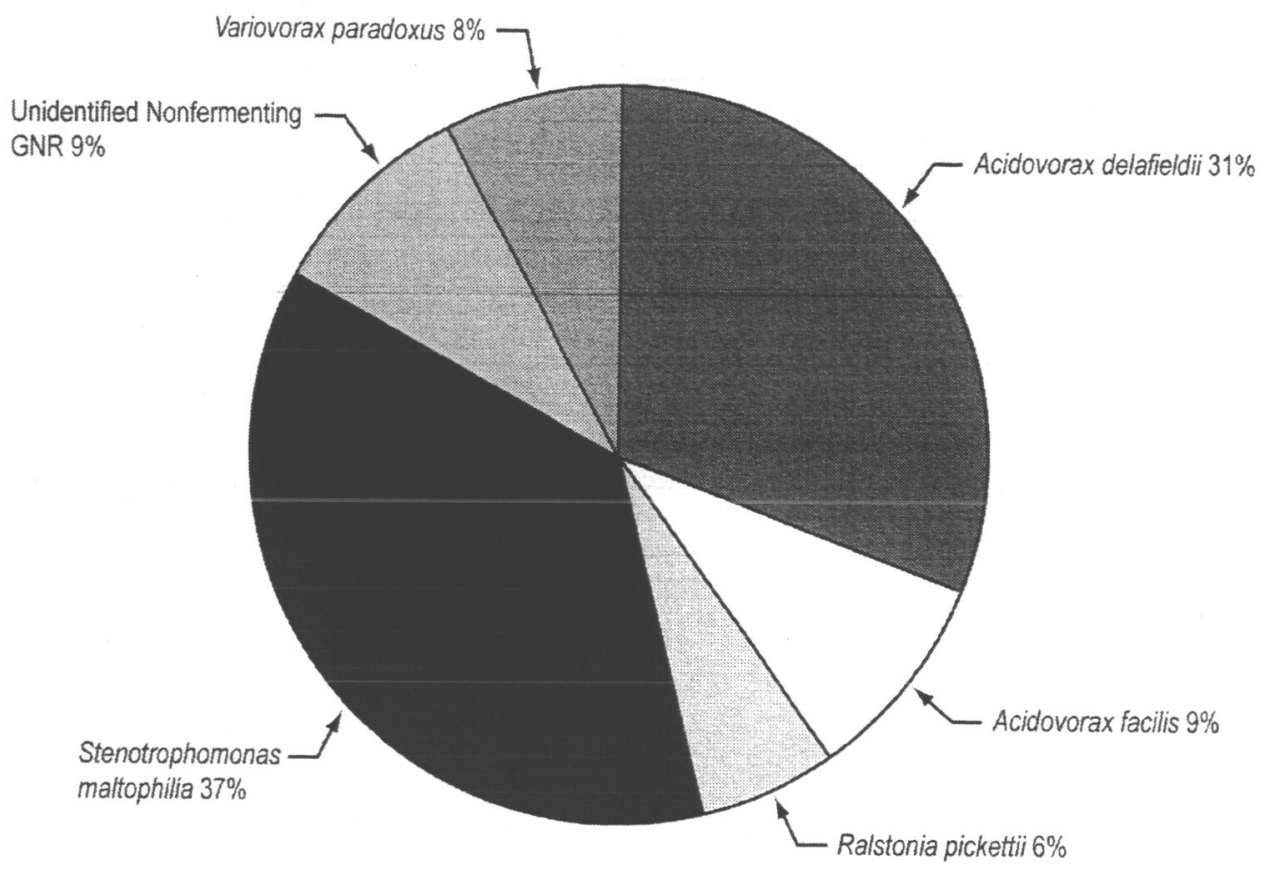

Figure 7. Micro-Organisms Identified in the Fleet Leader Ground Test $\mathrm{HTF}$ Before the Addition of $\mathrm{CO}_{2}$ and Consequent Decrease in pH

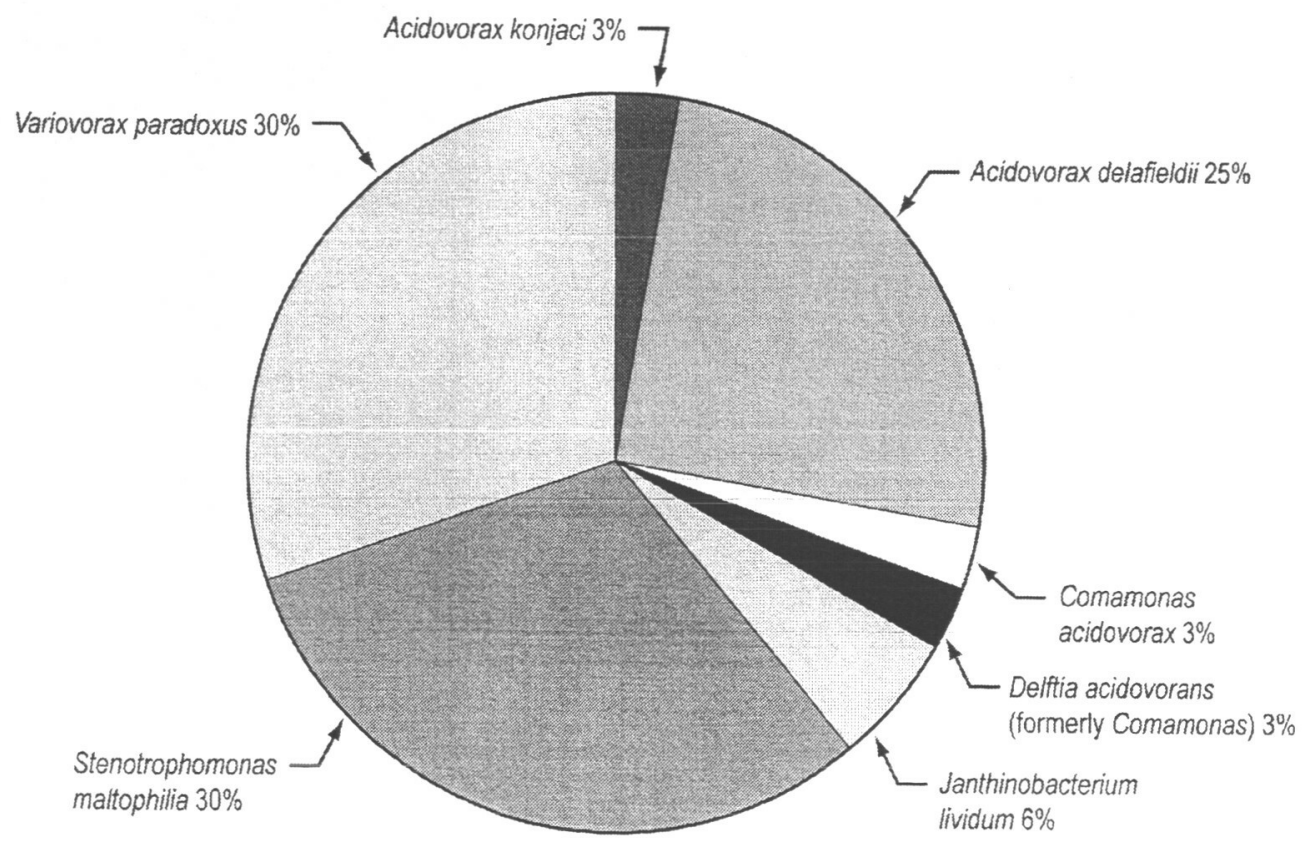

Figure 8. Micro-Organisms Identified in the Fleet Leader Ground Test HTF After the Addition of $\mathrm{CO}_{2}$ and Consequent Decrease in pH 


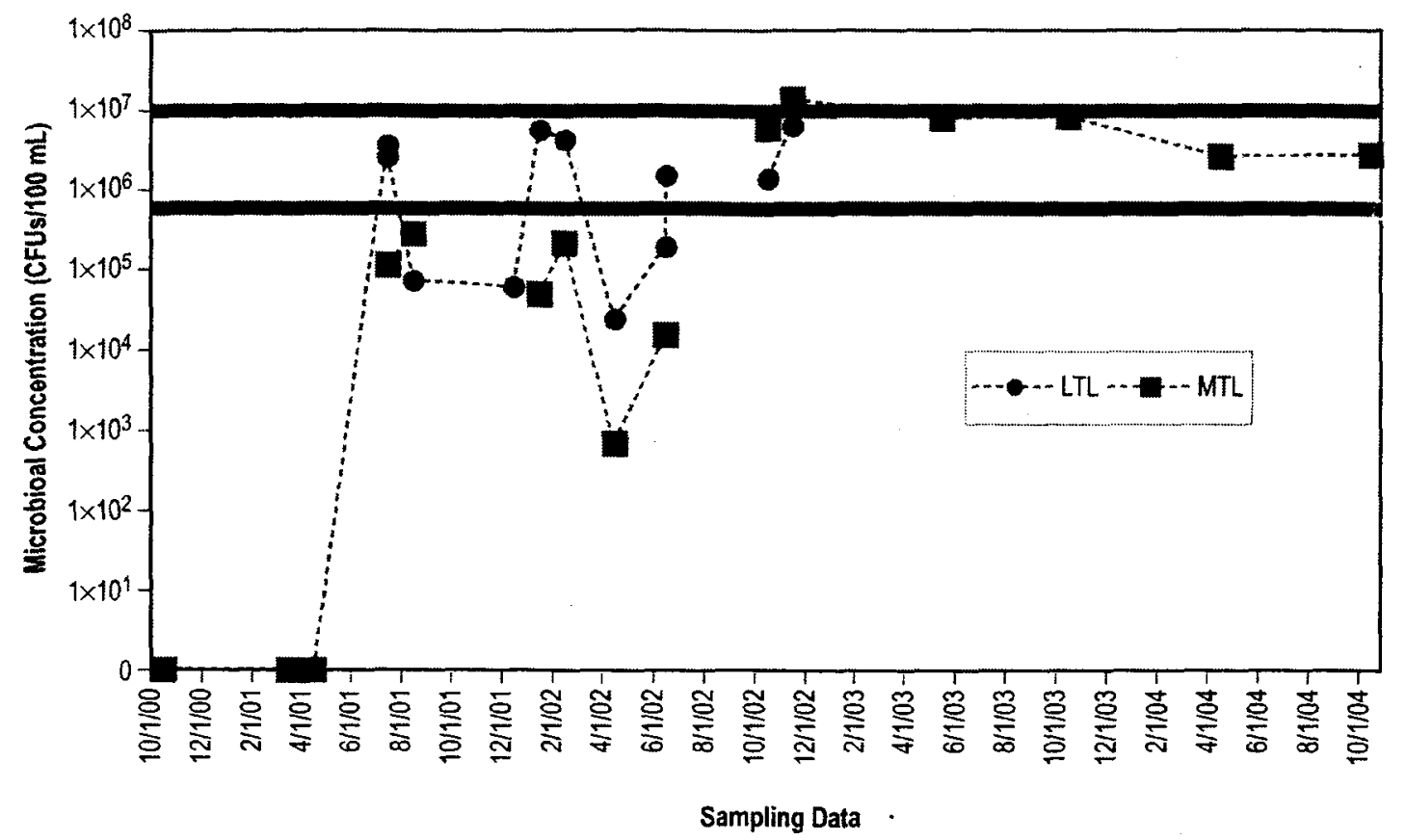

Figure 9. Microbial Concentration in the ISS IATCS Moderate- and Low-Temperature Loop HTF

While the ISS IATCS loops were independently operated, MTL and LTL samples were collected. Most of the time, the microbial population in the LTL was at least 1 log higher than the population in the MTL. The increases in the microbial population do not seem to be a response to the increase in the TOC concentration. Until January 2003, the TOC concentration in the fluid was well below $25 \mathrm{mg} / \mathrm{L}$. The TOC concentration in the fluid increased to $71 \mathrm{mg} / \mathrm{L}$ in the sample collected during the $5 \mathrm{~S}$ mission (May 2003) and has remained at that level. The main component of the TOC is ethyl alcoholthe source unknown at this time. Interesting is that the microbial population in the fluid has not significantly increased as a result of the TOC increase. This can be due to the type of bacteria identified in the fluid.

The majority ( $45 \%$ and $31 \%$ ) of the bacteria isolated from the ISS IATCS fluid could not be identified. They were reported as nonfermenting Gram negative rods (GNRs). A high percentage of the bacteria identified in the fluid was Acidovorax spp. and Ralstonia spp. Other bacteria isolated less frequently included Comamonas acidovorans, Sphingobacterium spiritovorum, and Brevibacterium casei. Figures 10 and 11 provide the percentage of micro-organisms of the individual species identified in the samples. Table 4 contains the list of microorganisms that were identified in the HTF fluid during ground test, ground processing, and in flight. Many of the organisms identified in fluid from ground testing and ground processing are also found in the flight fluid.

\section{MICROBIOLOGICAL CHALLENGES}

HOLDING TIME - Microbiological examination of $\mathrm{H}_{2} \mathrm{O}$ samples should start promptly after sample collection. Samples that cannot be processed within $1 \mathrm{hr}$ should be cooled during transport to the laboratory, and the time elapse between collection and examination should not exceed $24 \mathrm{hr}$. [8] It is documented that exceeding the holding time recommended by Standard Methods for the Examination of Water and Wastewater may produce injury, act as a secondary stress to some microorganisms, and/or allow the proliferation of others. It is important to take into consideration holding time when

interpreting results from microbiological analysis. The average holding time for the IATCS fluid samples returned from ISS was $16 \mathrm{~d}$ (maximum of $87 \mathrm{~d}$; minimum of 4 d). In addition, samples are not to be refrigerated for days after collection because there is no access to refrigeration facilities on the ISS or the orbiter. Actual counts and/or microbial composition of the ISS IATCS fluid might be different from what is documented. The development of in-flight microbial analyses tools, compatible with the IATCS fluid chemistry and microbial counts, will provide a better assessment of the microbial population. 


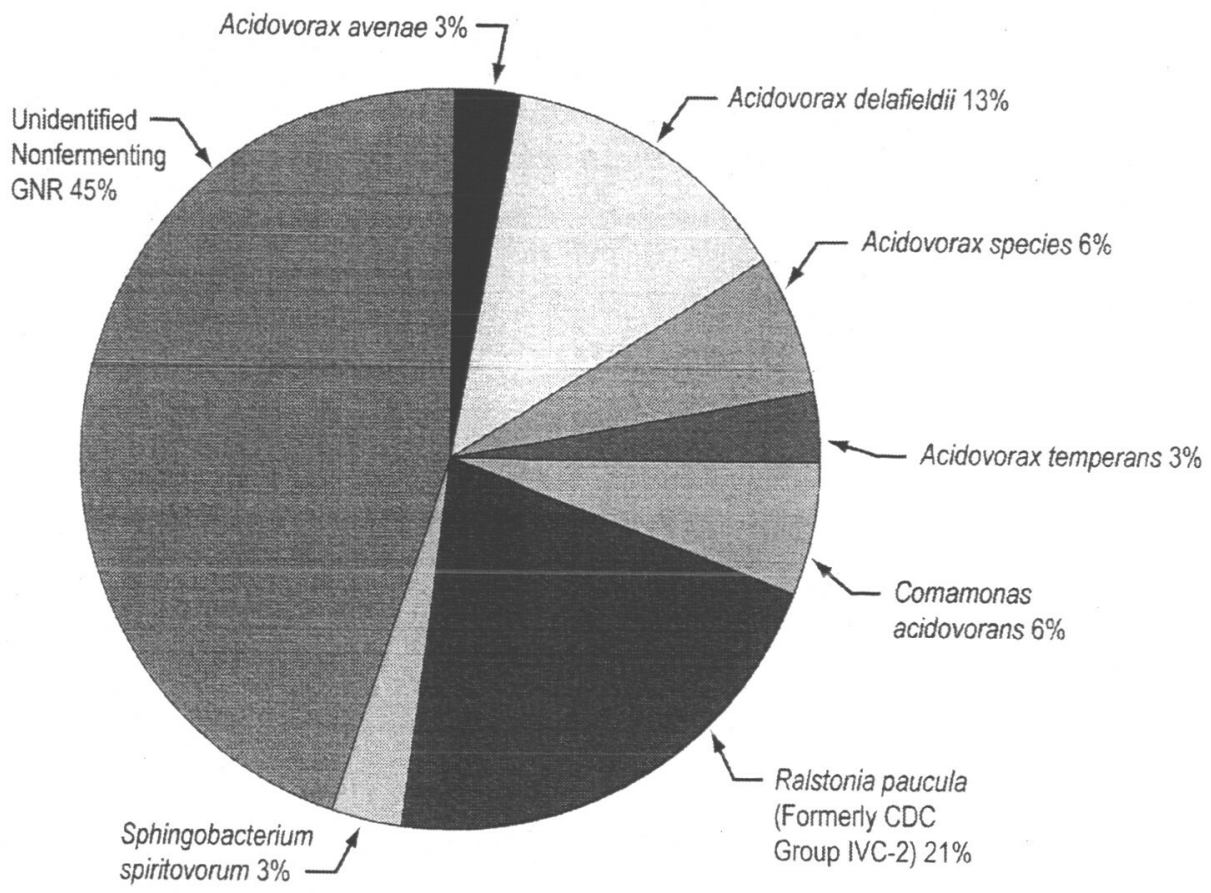

Figure 10. Percentage of Micro-Organisms Identified in all Samples From the ISS IATCS Low-Temperature Loop

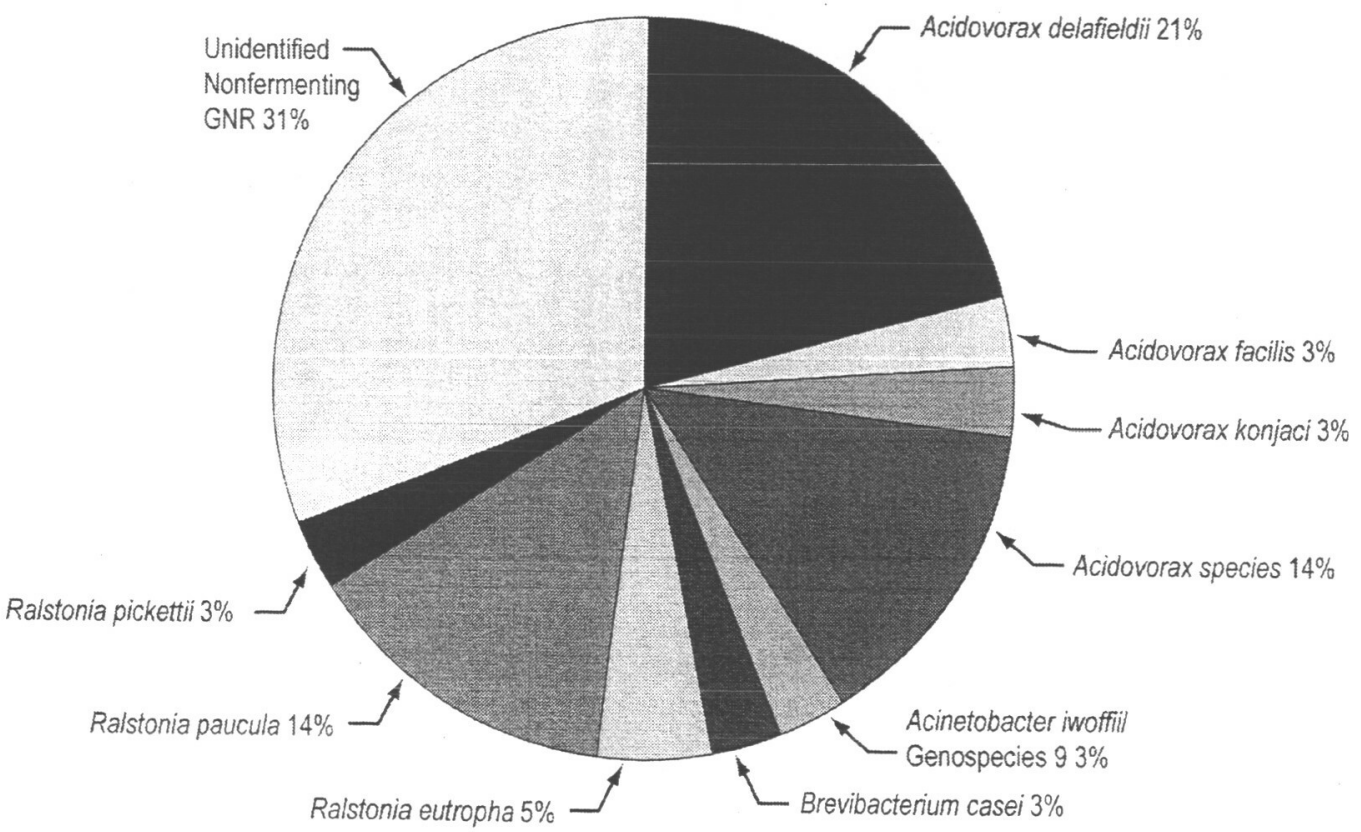

Figure 11. Percentage of Micro-Organisms Identified in all Samples From the ISS IATCS Moderate-Temperature Loop 
Table 4. Micro-Organisms Isolated From Prelaunch HTF, the Fleet Leader Test, and ISS Low- and Moderate Temperature Loop HTF

\begin{tabular}{|c|c|c|c|c|}
\hline Micro-Organisms & $\begin{array}{l}\text { Prelaunch } \\
\text { (Ground } \\
\text { Analysis) }\end{array}$ & $\begin{array}{l}\text { Fieet Leader } \\
\text { (Ground } \\
\text { Test) }\end{array}$ & $\begin{array}{l}\text { ISS LTL } \\
\text { (Flight } \\
\text { Fluid) }\end{array}$ & $\begin{array}{l}\text { ISS MTL } \\
\text { (Flight } \\
\text { Fluid) }\end{array}$ \\
\hline $\begin{array}{l}\text { Acidovorax avenae } \\
\text { Acidovorax delafieldii } \\
\text { Acidovorax facilis } \\
\text { Acidovorax konjaci } \\
\text { Acidovorax temperans } \\
\text { Acinetobacter Iwoffii } \\
\text { Brevibacterium casei } \\
\text { Brevundimonas vesicularis } \\
\text { Burkholderia glumae } \\
\text { Comamonas acidovorans } \\
\text { Flavobacterium resinovorum } \\
\text { Janthinobacterium lividum } \\
\text { Methylobacterium species } \\
\text { Oligella species } \\
\text { Ralstonia eutropha } \\
\text { Ralstonia paucula } \\
\text { Ralstonia pickettii } \\
\text { Sphingobacterium spiritovorum } \\
\text { Sphingomonas paucimobilis } \\
\text { Stenotrophomonas mattophilia } \\
\text { Unidentified nonfermenting } \\
\text { Gram negative rod } \\
\text { Variovorax paradoxus }\end{array}$ & $\begin{array}{l}x \\
x\end{array}$ & $\begin{array}{l}x \\
x \\
x\end{array}$ & $\begin{array}{l}x \\
x\end{array}$ & $\begin{array}{l}x \\
x \\
x \\
x \\
x \\
x \\
x \\
x\end{array}$ \\
\hline
\end{tabular}

MICROBIOLOGICAL ANALYSES - Microbiological analyses performed on the IATCS fluid are limited by the amount of sample that can be taken in flight and returned to the ground. Heterotrophic plate counts, using member filtration and R2A media, provides an estimation of the live heterotrophic bacteria in the fluid. Since this analysis has been performed on the fluid consistently for many years, it provides a good indication of microbial changes over time. The modification of the $\mathrm{H}_{2} \mathrm{O}$ microbial kit currently used on the ISS for the analysis of potable $\mathrm{H}_{2} \mathrm{O}$, will provide the capability of analyzing the IATCS fluid for heterotrophic bacteria in flight, minimizing holding time.

HPC provides basic information on the heterotrophic population in the IATCS fluid, but as with any other culture-based microbial analysis, only a very small portion of the population is isolated and identified. [8] As technology advances, so will the possibilities for in-flight analysis of anaerobes, specific pathogens, and bacteria known to damage material. This will provide a better understanding of the microbial population in IATCS fluid. New microbiological technologies, like Lab-on-a-chip, based on genetic identification of bacteria, will minimize the holding time and significantly reduce the time from sample collection to reporting of results.

Analyses of fluid samples cannot be used to provide an assessment of biofilm formation or microbiologically influenced corrosion (MIC) on hardware surfaces. [8] In the future, coupons strategically placed in the IATCS loops can be periodically returned to the ground. Analyses of these coupons will be the best approach in assessing the likelihood of hardware performance problems due to biofilm and/or MIC.

ADDITION OF ANTIMICROBIAL - From the data obtained, it is clear that the conditions in the IATCS fluid can support microbial growth if an antimicrobial is not added. A safe and effective antimicrobial to control the microbial population in the fluid and decrease the risk of hardware performance issues due to biofilm or MIC is needed. At this time, it is hard to predict the benefits of adding an antimicrobial, since the surfaces of Node 1, USL, and Airock, are already colonized with bacteria. It is likely that the bioaccumulation on the surfaces of this flight hardware will never be completely removed; therefore, hardware currently in flight, unless replaced, will always be at risk, even after the addition of an antimicrobial. Despite that, control of the microbial population in the flight fluid is important and recommended.

The benefits of adding an antimicrobial to the IATCS fluid of hardware that will be launched in the future are many, including the protection of surfaces before microorganisms start to colonize the surfaces. A study to determine what antimicrobials could be used in the ISS IATCS is currently being performed. $[9,10]$

GROUND CONTROLS - The data from analyses of flight hardware IATCS fluid, while on the ground, show that 
without procedures to control the microbial population, the concentration of bacteria can be as high as $10^{7} \mathrm{CFUs} / 100 \mathrm{~mL}$. The addition of $0.2-\mu$ filters in the GSE and disinfection with $3 \% \mathrm{H}_{2} \mathrm{O}_{2}$ has succesfully minimized the contamination. The establishment of acceptable microbiological limits and scheduled monitoring will help assess the hardware before it is launched.

\section{SUMMARY AND CONCLUSIONS}

The ISS HTF heterotrophic microbial population has not significantly changed (more than $1 \mathrm{log}$ ) since October 2002. It stabilized at a concentration of $10^{6}$ CFUs/ $100 \mathrm{~mL}$. It is possible that the population could have reached that level earlier if $\mathrm{Ag}$ would have not been added to the fluid in January 2002. It is not surprising that the HTF in the ISS elements currently operational is contaminated. The HTF fluid in many of the payload racks could have had a microbial population as high as $10^{7} \mathrm{CFUs} / 100 \mathrm{~mL}$ when launched and connected to the loops. In addition, changes in the flight HTF chemistry have made the fluid environment favorable for microbial growth. The main change affecting this was the decrease of available antimicrobial $(\mathrm{Ag})$. The $\mathrm{pH}$ decrease could have also affected the microbial population; as $\mathrm{pH}$ decreased -9.5 to 8.4 , an increased number of bacterial species could grow in the fluid.

The development of an in-flight microbial monitor for the IATES HTF will decrease concerns with sample storage and preservation. Currently, it can take as long as $84 \mathrm{~d}$ before a sample is analyzed on the ground. As the holding time is decreased, the chances of detecting predominant bacteria and bacteria of concern in the system increases. The addition of coupons in the ISS IATCS loops to assess biofilm accumulation and potential damage to surfaces will also be important. The deletion of $\mathrm{PO}_{4}$ from the IATCS fluid should help minimize microbial growth in the future because bacteria can use $\mathrm{PO}_{4}$ as a nutrient. Ground procedure changes, some of them aiready implemented (like the use of $0.2-\mu$ filtration), will also help minimize problems in the future.

Micro-organisms identified in the flight fluid have also been identified in the fluid from ground tests and/or GSE. This suggests that the contamination of the fluid originated on the ground, while the fluid was prepared, and/or during ground processing. The micro-organisms identified are commonly found in $\mathrm{H}_{2} \mathrm{O}$ systems. The list of the micro-organisms was reviewed by the Johnson Space Center flight surgeon and no health hazard to the crew was identified. Some of the bacteria identified could potentially degrade materials under certain conditions, but it is not possible to know the damage they have caused to the hardware, if any, until samples of materials returned from the ISS can be examined. It is impossible to quantify the biofilm accumulated on the hardware surfaces using only the data that is currently available. The combination of ground tests and analysis of flight hardware currently planned will help assess biofilm accumulation and the risk of MIC.

There is no reported problem in either of the IATCS loops that could be solely attributed to the fluid microbial load. Despite that, the addition of a safe and effective antimicrobial to the fluid is desirable and strongly recommended. The addition of an antimicrobial to the fluid could potentially increase the hardware life of the onorbit elements already exposed to a microbial concentration of $10^{6} \mathrm{CFUs} / 100 \mathrm{~mL}$. It could also minimize bacterial attachment to hardware surfaces for the elements that will be launched in the future, decreasing the risk of performance issues.

\section{ACKNOWLEDGMENTS}

The authors would like to acknowledge the analyses performed by Natalee Weir and Harold Cole, The Boeing Company, Huntsville, and Randy Sumner, The Bionetics Corporation, in support of this project. We would like to thank Mike Holt and Robert Wark, NASA, for providing historical data (prelaunch) for this paper. The authors would also like to express gratitude to the ISS IATCS System Problem Resolution team, especially the members of the Biocide subteam and the Microbiologically Influenced Corrosion subteam.

\section{REFERENCES}

1. Space Station Program Fluid Procurement and Use Control Specification, SSP30573, Rev. B, dated March 1, 1998.

2. Van der Kooij, D.; Visser, A.; and Hijinen, W.: "Determining the Concentration of Easily Assimilable Organic Carbon," J. AWWA, Vol. 74, pp. 540-545, 1982.

3. Boeing Memorandum 2-1061-LHE-003-NEW; From Natalee Weir (Huntsville Laboratories Analytical Services Microbiology) To Sam Woodward (Sustaining Engineering), March 10, 1999.

4. Daugherty, R.S.; and Golden, J.: "High TOC Readings in the Lab ITCS Loops and HXs," Internal Presentation, The Boeing Company, November 9, 2000.

5. Daugherty, R.S.; and Chambliss, J.P.: "Development of an Integrated Design Resoltuion Plan for the International Space Station Active Internal Thermal Control System Coolant Stability Concerns," SAE Technical Paper No. 2001-012333, presented at the 2001 ICES Conference,

6. Pandya, M.T., "Microorganisms in Recirculatory Water Systems and Their Significance in Fouling," 
National Water Quality Monitoring Council 2000 Conference Proceedings, Austin, TX, 2000.

7. Standard Methods for the Examination of Water and Wastewater, 19th ed., pp. 9-31-9-38, APHA, AWWA, WEF, Washington, DC, 1995.

8. Hurst, C.J. (ed): Manual of Environmental Microbiology, 2nd ed., pp. 101-209, 1072-1083, ASM Press, Washington, DC, 2002.

9. Wilson, M.; Cole, H.; Weir, N.; et al.: "Selection of an Alternate Biocide for the International Space Station Internal Active Thermal Control System Coolant Loops," SAE Technical Paper 2003-01. 2568, 2003.

10. Wilson, M.; Cole, $H_{\text {.; }}$ Weir, N.; et al.: "Selection of an Alternate Biocide for the International Space Station Internal Active Thermal Control System Coolant Loops," SAE Technical Paper 2004-01$2472,2004$.

\section{ACRONYMS AND SYMBOLS}

\section{$\mathrm{Ag}$ \\ $\mathrm{AgPO}_{4}$ \\ $\mathrm{AOC}$ \\ CFU \\ $\mathrm{CO}_{2}$ \\ CS \\ EDTA \\ ER} EXPRESS (expedite the processing

$\begin{array}{ll}\text { FSS } & \text { fluid system servicer } \\ \text { GNR } & \text { Gram negative rod } \\ \text { GSE } & \text { ground support equipment } \\ \mathrm{H}_{2} \mathrm{O} & \text { water } \\ \mathrm{H}_{2} \mathrm{O}_{2} & \text { hydrogen peroxide } \\ \mathrm{HRF}_{2} & \text { human research flight rack-2 } \\ \mathrm{HTF} & \text { heat transport fluid } \\ \text { IATCS } & \text { Internal Active Thermal Control System } \\ \text { ISS } & \text { International Space Station } \\ \text { KSC } & \text { Kennedy Space Center } \\ \text { LTL } & \text { low-temperature loop } \\ \text { MELFl-1 } & \text { minus eighty-degree laboratory freezer } \\ & \text { for ISS flight unit 1 } \\ \text { MIC } & \text { microbiologically influenced corrosion } \\ \text { MSFC } & \text { Marshall Space Flight Center } \\ \text { MTL } & \text { moderate-temperature loop } \\ \mathrm{NH} & \text { ammonia } \\ \mathrm{Ni} & \text { nickel } \\ \text { PO } & \text { phosphate } \\ \text { PPA } & \text { pump package assembly } \\ \text { SSPF } & \text { Space Station Processing Facility } \\ \text { SSP } & \text { Space Station Program } \\ \text { TIC } & \text { total inorganic carbon } \\ \text { TOC } & \text { total organic carbon } \\ \text { UF } & \text { utilization flight } \\ \text { USL } & \text { United States Laboratory } \\ \text { USOS } & \text { United States on-orbit segment } \\ & \\ & \end{array}$

$\begin{array}{lll}\text { silver } & \text { SSP } & \text { Space Station Program } \\ \text { silver phosphate } & \text { TIC } & \text { total inorganic carbon } \\ \text { assimilable organic carbon } & \text { TOC } & \text { total organic carbon } \\ \text { colony-forming unit } & \text { UF } & \text { utilization flight } \\ \text { carbon dioxide } & \text { USL } & \text { United States Laboratory } \\ \text { coolant servicer } & \text { USOS } & \text { United States on-orbit segment }\end{array}$
of experiments to Space Station) rack 